\title{
CONFESSION, DISSIMULATION, AND STORYTELLING IN THE UR-TEXT OF CLASSICAL EROTICISM
}

In his Salon de 1846, Baudelaire has a section entitled "Des sujets amoureux et de M. Tassaert." He imagines the creation of a "love museum" where love, in all its forms, from innocent to debauched, would be represented. He would place Tassaert's lithograph,--"Ne fais donc pas la cruelle,"--in this museum; it depicts a young man dressed as a woman, and his mistress dressed as a man, seated on a sofa; the woman tries to lift up the young man's skirt. Baudelaire remarks that this lithograph expresses "une des grandes vérités de l'amour libertin"--he cites, in a footnote, lines from the 1678 version of Nicolas Chorier's Dialogues de Luisa Sigea (originally published 1660):

Sedebant in fornicibus pueri puellaeve sub titulis et lychnis, illi femineo compti mundo sub stola, hae parum comptae sub puerorum veste, ore ad puerilem formam composito. Alter venibat sexus sub alter sexu. Corruperat omnis caro viam suam.'

The subject of both Tassaert's lithograph and the passage from Chorier is transvestism. But, while Tassaert's image depicts a heterosexual role-swapping situation, the passage from Chorier was drawn from a larger discussion of sodomy and sexual practices associated with it, referred to as: "cet usage des garçons et des filles, de mentir à leur sexe."

Evidently what interests Baudelaire in these two entries to his Love Museum is not the sexual practices themselves but rather the connection between desire and appearances, love and deceit, sexual orientation and lies. It is not surprising that he should choose to substantiate his claim that this forms one of the great truths of libertine

' Baudelaire, Charles. Oeuvres complètes, vol. II, ed. by Claude Pichois, Paris: Gallimard, 1976 p.443-445and note. "Sous l'écriteau et sous la lampe, dans les lupanars, se tenaient assis des garçons et des filles, ceux-là omés sous la stola d'ajustements féminins, celles-ci habillees en hommes sous la tunique, et la chevelure arrangée à la mode des garçons. Sous l'apparence d'un sexe, on trouvait l'autre. 'Toute chair avait corrompu sa voie."

${ }^{2}$ All references are to the 1969 edition Des secrets de l'amour et de Venus: satire sotadique de Luisa Sigea de Tolede. 2 vols. Paris: l'Or du Temps. Preface by André Berry. II, p. 69. 
love by citing Nicolas Chorier's Dialogues. Though little known today, this was by far the most influential of 17th-century European erotic works and the ur-text of classical eroticism.

Lies express great truths: Baudelaire must have had a thorough knowledge of this two-hundred year old erotic text because, for even greater authoritative effect, he cites it in Latin, the erudite language of the rather scarce early editions. ${ }^{3}$ "Latin lies express great truths" could easily have been the subtitle of Chorier's infamous book.

Nicolas Chorier was a lawyer born in Vienne, Dauphiné. His publications date from about 1640 and include a Philosophie de l'honnête homme. He moved to Grenoble in 1658 and there, in 1661, the first volume of his Histoire généraledu Dauphiné was published. The Dialogues de Luisa Sigea were first published in 1660 and the Latin title--Aloisiae Sigoeae Toletanae Satyra Sotadica de arcanis amoris et Veneris. Aloisia hispanice scripsit, latinitate donavit Joannes Meursius V. C.,(Sotadic satire on the secrets of love and Venus by Luisa Sigea of Toledo)--contained a blatant lie all the more scandalous because, for a while at least, it sullied the reputations of two real people, Luisa Sigea and Jan de Meurs. Luisa Sigea was in fact an important young polyglot at the Lisbon court in the middle of the 16th century; like Tullia, the main character in the Dialogues, she was renowned for her intellect and was considered "la Minerve de son siècle"; Jan de Meurs was a Dutch historian and humanist who died in 1653 , seven years before the publication of the Dialogues. Thus, both the supposed author and the supposed translator of the book were dead at the time of its publication and therefore incapable of defending themselves against the attribution of this obscene work. In fact, the lying Latin title was persuasive enough to tie their names inextricably into the history of the text: well into the 19th century, and despite bibliographers' awareness of the hoax, one might still refer to Chorier's text as the Meursius, or Aloysia. Paradoxically its polished Latin was also one of the first things to reveal the true provenance of the book; insiders began to suspect Chorier, a published latinist, of having written it. Chorier's pride in his command of the scholarly language was such that, after denouncing the book and denying that he had anything to do with it, he couldn't help but add that its Latin was "d'un style élégant et fleuri." He wrote in his memoirs: "Lorsque tout d'abord elle tomba entre les mains des hommes, comme nul

\footnotetext{
${ }^{3}$ A French translation came out as early as $1680--L$ 'Académie des dames divisée en sept entretiens satiriques--and numerous translations, including Italian, German, and English, appeared over the next two centuries.
} 
n'ignorait que je fusse savant en latin, je ne sais quels lettrés me soupçonnèrent perfidement et injurieusement d'être l'auteur de cette Satire. "4 "Into the hands of men"--- Chorier puts his finger on another paradox: the Dialogues de Luisa Sigea, supposedly written by a woman, recording the conversations of two women, and containing information pertaining directly to women, was destined for a limited audience of educated men, that community of Latin-reading lettrés, all friends and enemies. Even the lying Latin title maintains some degree of verisimilitude with its claim that the book was written in the vernacular by a woman and translated into Latin by a man: in the 17th century few women, including the most erudite among them, would have had the education necessary to write in Latin; a female author would most likely have needed a man to translate her into this very virile language.

For an educated male readership the contrast must have been provocative between the studious and philosophical Latin that they learned as schoolboys and the subject matter of the Dialogues, which deal specifically with feminine pleasure and sexual education. Like women dressed in men's clothing, the Dialogues are a transvestized literary object in which a pseudo-female author invents female characters to talk intimately about feminine sexual education in a male tongue and for a male audience.

Like most classical literature based on ancient sources, the Dialogues de Luisa Sigea represent, a telescoping of early-modern literary concerns; we have, in this case, the development of a specifically erotic genre in literature--a set of Greek and Roman themes--and the philosophical dialogue and pedagogical practices associated with it. In its straddling of the centuries, it addresses two important moments in the history of sex: what Michel Foucault calls the 17th century's "mise en discours" of sex, the insistence that (specifically) women should speak about sex, recount it in detail, confess it; and the comprehension of sex, in ancient Greek culture, as one aspect of a "Diététique", where the proper regulation of sexual activity is seen as contributing to an ethics based on the stylization of the subject. In this article I plan to expand the definition of a classical erotic literary discourse by demonstrating that a preoccupation with women's intellectual and sexual instruction was central to that discourse and to the most important erotic text of the 17th century.

Chorier's Dialogues attempt to fashion a new erotic rhetoric from,

\footnotetext{
4 Cited by André Berry (p. xxi) in the preface to Des secretsde l'amour et de Venus: satire sotadique de Luisa Sigea de Tolede.
} 
on the one hand, the portrayal of a young girl's eroto-philosophical education--her construction of the self and stylization of her existence through her own control over and articulation of her sexual activities; and, on the other, from the redirection of Western confessional practices aimed at revealing, through her discourse, the "truth" of the subject, toward an erotic art of storytelling and tall tales where sexual activity is sublimated into language. What follows is a brief summary of the text.

The Dialogues de Luisa Sigea relate, in a series of conversations, the sexual initiation of a young ingenue. In the first dialogue, on the eve of her wedding, Ottavia spends the night in the bed of one of her mother's friends, Tullia. Tullia is a married woman, famous for her erudition, for her command of Greek, Latin, and "presque tous les arts libéraux." She has been asked by Sempronia, Ottavia's mother, to talk to the young bride about sex, to explain to her what her new husband will surely want to do on their wedding night, to prepare her to make the proper response, that is, to be obedient but not everly enthusiastic.

Tullia's pedagogical approach vacillates between theory and practice. She prepares Ottavia for her wedding night by initiating her into the pleasures of lesbian sex. Having thus piqued her pupil's curiosity, Tullia delves into lectures on the Greek and Latin names for body parts, she recounts the history of lesbianism, sodomy, and dildos, she piles anecdote upon anecdote in order to demonstrate the various positions and places conducive to sex.

A second dialogue begins at some point not long after Ottavia's wedding night. Ottavia recounts in detail the loss of her virginity and her first orgasm. Tullia responds by first praising the institution of marriage and the sovereignty of the husband. Then, with artful sophistry she successfully reshapes her student's understanding of such things as wifely honor and fidelity. She reasons that a woman's happiness depends upon marriage, and this because from the security and under the shelter of marriage everything is permitted. She reveals the licentiousness of Ottavia's mother, Sempronia, and encourages Ottavia to imitate her mother's duplicitous lifestyle. Tullia has arranged for the first lesson in deceit and infidelity to take place the following night: a certain Lampridio, Tullia's own lover, will be Ottavia's escort as Tullia initiates her into a new life of adultery.

The next dialogue is entitled "Façons et figures." Ottavia, Tullia, Lampridio, and a fourth character, Rangoni, stage, in the course of innumerable sexual episodes, a series of contortionist tableaus illustrating a seemingly endless variety of sexual positions.

The last dialogue transfers the location of the action from Italy to 
Spain, without, however, changing the characters. This is the most overtly pedagogical of the chapters, it has been called an art d'aimer punctuated by anecdotes and little stories. When to make love, how often, in what positions, along with discussions of anatomy, erotic art, and "unnatural" acts, make up this final dialogue.

In the first half of the 17th century there was one predominating image of the sexual instructor. An old, ugly, sometimes sorceress, always mercenary, entremetteuse. Her most famous portrayal in French is to be read in Mathurin Régnier's 13th Satire "Macette" (1612). "Macette" was immediately preceded by de L'Espine's satire of an entremetteuse ("Discours du Sieur de l'Espine," 1609), and by a Renaissance version of the figure as she appears with the leading role in the Spanish play by Fernando de Rojas La Celestina (fourteen French editions in the 16th century). But the figure is found in Plêiade poets - Ronsard's Catin ("IIle Folastrie", 1553), and Du Bellay's "Antérotique de la vieille et de la jeune amie" (1549), - and extends back through "La Vieille" of the Roman de la Rose to Ovid's "Dipsas, "the obvious source and model for practically all later portrayals (Amores I,viii). ${ }^{5}$ In La Celestina, the pedagogue of female infidelity teaches the young ingenue how to make use of her feminine charms. She represents the intrusion of the physical (sexual) world, as well as the social world, into the cloistered environment in which the young girl has been kept intellectually and sexually innocent. The old woman gains access to this sheltered space by means of the ultimate feminine guile: an apparent insignificance in her movements and business. Celestina comes to sell a bit of thread, or she offers to repair a dress. An early-modern Avon lady, she goes door to door, providing little, superfluous and inessential things, some ribbon, face-cream, an herb or two. The old lady's conversation seems, on the surface, to be mere female chatter, but, in fact, a certain kind of her persuasive chatter is for sale: subsidized by an amorous suitor, Celestina's discourse becomes a kind of lobbying activity whose aim is to convince the young girl to accept the suitor's advances.

\footnotetext{
s An even older figure of this type is found in the legend of Lilith, Adam's first wife who, because she was created at the same time as Adam, refused her subordinate sexual role and fled from him, preferring to fulfill her sexual fantasies with demons. She became a popular image during the Middle Ages, an evil spirit responsible for infant death, abortion, contraception, and wifely infidelity. Olga Trtnik-Rossettini's book, Les influences anciennes \& italiennes sur la satire en France au XVle siecle. Firenze: Institut Français de Florence. 1958, devotes a chapter to satires against the entremetteuse and the courtesan.
} 
In the 1530's Pietro Aretino provided another version of the entremetteuse in the Ragionamenti. These dialogues between Nanna, a prostitute, her friend Antonia, and her daughter Pippa were spread over six days and treated the various states of women, including the lives of nuns, wives, and whores. In the opening dialogue, the prostitute Nanna recounts her sexual apprenticeship as a young nun in a convent. This convent, a cloistered, secretive place not unlike a Sadian château, has a ceremonial room hung with paintings of "all the various modes and avenues by which one can fuck and be fucked " and there is a mistress who teaches the sexual positions. These paintings are certainly a reference, not only to the fixed set of sexual positions reputed to have been painted and practiced by the Greeks and Romans, but to the images of erotic positions engraved after Giulio Romano for which Aretino wrote a corresponding set of sonnets, known as the Sonneti lussuriosi. Aretino's reputation for pornography is based in large part on his relationship to this set of engravings, which have come to be known as the "Aretino-Romano posizioni".

Significantly, in those dialogues of the Ragionamenti where Nanna teaches her daughter the prostitute's art, these sexual positions are never actually described, nor are they taught as the "tricks of the trade". The Ragionamenti are, like Ovid's Ars amatoria, de Rojas' Celestina, and Regnier's "Macette", essentially cynical; the world is represented as consisting of exploiters and exploited. For women, sex is a livelihood, not a pleasure. What Aretino's entremetteuse teaches is not an erotic art of positions and practices, not how to derive pleasure from sex, but how to exploit men rather than be exploited by them.

This cynical concept is emblematized in the figure of the entremetteuse: hypocritical and evil, she is a manipulative old woman ruined by a lifetime of sexual debauchery; she schemes to influence a young girl to sell her favors only for money and always to the highest bidder. Her interested advice (she hopes to be "remembered" by the young girl's rich suitors) conflicts with the desire of the penniless poet/narrator who has come to court the girl and hides at the door in order to overhear the sorceress' odious counsel.

Her strategy vis-à-vis the young woman varies little from one author to another. She insinuates herself into a respectable home while the mother is away and after a few reassuring remarks about her religious practices or her longstanding friendship with the family, she begins to deliver her lessons in hypocrisy:

Ces vieux contes d'honneur dont on repaist les Dames 
Ne sont que des appas pour les debiles ames,

Qui, sans chois de raison, ont le cerveau perclus.

and:

L'honneur est un vieux sainct que l'on ne chomme plus.

Celle est chaste, sans plus, qui n'en est point priée. ${ }^{6}$

Once she has her pupil's attention, she moves on to more practical advice: how to captivate men. She instructs the young girl to dress so as to make the most of her physical beauty; that is, she should implement a strategy of calculated negligence:

[que] Ces deux jeunes tetons soient voilez d'un mouchoir

Qui d'un point bien ouvré quelque fois puisse choir...?

The old lady next touches on a few points of love-making technique designed to imply passion barely bridled by innocence and modesty:

S'il passe plus avant, fay qu'à demy pressée,

Il semble que soubs luy tu demeures forcte.

Et lors comme renduề après tous tes efforts,

Abandonne à sa loy les beautez de ton corps,

Serre-le doucement, et d'une humide bouche

Entr'ouverte à demy, fay que ta langue touche

A sa langue amoureuse; après retire-la,

Faignant te repentir d'avoir osé cela...

Eventually she gets to the real point of her lesson. She must convince the young girl that all this love-making has not so much pleasure as its goal but economic gain. "Join the useful with the pleasurable":

Estimez vos amans selon le revenu:

c. f. Ovid, Amores, $1,8,43$. Casta est quam nemo rogavit.

'Similar advice is to be found in the discourse of la vieille in Le roman de la rose, lines 13313-13318: S'ele a blanc col et gorge blanche,/ Cart que cis qui sa robe trenche / Si tresbien la li escolete / Que sa char pere blanche et nete / Demi pié derrier et devant,/ Si en sera plus decevant.

- La vieille of Le roman de la Rose is even more prescriptive in her hypocrisy; she goes so far as to suggest that the woman fake orgasm. 
Qui donnera le plus qu'il soit le mieux venu.'

...Il ne faut simplement un amy qui vous plaise,

Mais qui puisse au plaisir joindre l'utilite.

En amour, autrement c'est imbecilité. (Regnier)

Finally, the old entremetteuse reveals her personal motives. She is procuring financial security for herself since she expects there to be wind-fall from all these wealthy lovers and she knows a grateful young girl would never stand by and watch her starve:
Alors j'espereray que par toy leur Déesse,
Leur bonté s'estendra sur ma foible vieillesse.
Et qu'un jour avenir, quand tu te souviendras
De ces reigles de vivre, à l'heure tu diras,
...:Icy gisent les os
De celle à qui je prie un eternel repos. ${ }^{10}$ (L'Espine)

Madeleine Maurel sees in the figure of the old woman a "baroque anteros" developed in reaction against the medieval idealization of woman and influenced by Renaissance antipetrarchan images." The popularity of the figure betrays a vein (at least) of misogynist sentiment at the beginning of the 17 th century indeed but also a curious fascination among "Satiric" poets (Auvray, Regnier, Sigogne, L'Espine) with the use of an "ugly" foil in their erotic works. The condemnation implicit in the description of the old crone and her discourse of sexual promiscuity probably went a long way to ensure that their works were viewed as generally supportive of traditional morals which required not only that women have no control over their sexual destinies (their husbands would see to that), but that they should have no knowledge of sex whatsoever. Satirizing as they did the sexual education of a young woman permitted satiric poets to both evoke images of erotic instruction and to condemn that instruction as coming from an illegitimate source - the hypocritical hag.

'Le roman de la rose: Biau fis, ja larges ne saies;/ En plusors leu le cuer aiés, / En un sel leu ja nel metés, / Ne nel donnés, ne ne pretés, / Mes vendés le bien chierement / Touz jors par enchierissement; (ll. 13037-13042).

${ }^{10}$ Amores, 1,8, 105-108. Haec si praestiteris usu mihi cognita longo, Nec tulerint voces ventus et aura meas, Saepe mihi dices vivae bene, saepe rogabis Ut mea defunctae molliter ossa cubent.

" "Esquisse d'un antéros baroque," XVII siècle, No. 84-85 (1969), pp. 3-20. 
Whether the rhetorical function of the figure of the entremetteuse was anti-feminist or erotic, or both, the character was embedded in erotic tradition in one form - old and ugly - until the middle of the 17th century. Then, a very important change took place, a change which, to my knowledge, has gone unnoticed and unexplored by scholars: in two erotic dialogues, L'Escole des filles (1655) and the Dialogues de Luisa Sigea the entremetteuse was transformed into a beautiful, young, sexually active, and knowledgeable woman. The satiric tradition gave way to a parody of the philosophical dialogue in which a character like Tullia, an erudite polyglot, would have the role of the sage. Her libertine education is no longer that of the sorceress but of a conjunction of humanism and reason. Not surprisingly, the eroticized philosophical dialogue abandons the advocation of sex for economic gain in favor of sex for personal pleasure and individual enlightenment.

For all that, "la vieille" is not completely missing from the Dialogues. She exists vestigially, as she will in Laclos (Les liaisons dangereuses), ${ }^{12}$ in Sade (Les cent vingt journées), in Balzac (La fille aux yeux d'or), in Baudelaire ("Les petites vieilles"), in Arsan's Emanuelle (1967), in the guise of someone's debauched old servant. She excites the curiosity, if not the desires, of the other characters: her sexual history is inscribed on her face and body in the form of wrinkles, chancres, and stretch-marks. Like "Macette" she gets her pleasure vicariously through the sexual encounters of her employers. She is always ready to lend a helping hand: Tullia's lover Lampridio recounts a story in the sixth dialogue in which an old governess physically helps him to deflower a young girl.

More importantly the Dialogues illustrate the transference of the procuress' role from the old woman to the young one as well as the old woman's empty vestigial presence. Tullia describes how she was befriended by a woman "d'un âge non encore très avancé", i.e. young, -Donna Orsini. Orsini takes Tullia under her wing, tells her to rely on her discretion and invites her to a suburban villa, (doubtless one of the lupanar's for rich Roman ladies so despised by Juvenal) where Tullia will spend the day cavorting with four "athlètes." At the door, Orsini hands her over to "une vieille femme": "'Je ferai en sorte,' dit [la vieille] en se tournant vers Donna Orsini, 'que cette jeune personne amenée par vous

\footnotetext{
${ }^{12}$ In the last letter of the novel, Merteuil, (in what has been seen as a merely formal punishment in comparison with the persuasiveness of her libertine philosophy spread over pages) contracts a venereal disease and becomes an ugly old hag - "son ame était sur sa figure."
} 
et qui avant peu de temps sera ivre de voluptés, vous en rende des grâces éternelles." "The mentor/procuress in this episode is clearly Donna Orsini; it is she who will receive, not money, but eternal thanks, the new reward consistent with the entremetteuse's more philosophical status. In Chorier, the figure of the old woman is a left-over, and, though she may still serve as a foil for the beauty of the protagonist, her pedagogical role has been usurped by that of a younger, educated woman who is still sexually active.

And how better to convince a young girl to indulge herself than with the new, improved, entremetteuse; for the clever student, the lesson of the two images should be obvious. The ugly old hag was a most convincing argument why not to have sex. Her appearance proved what sex did to a woman, it used her up, wore her out, made her ugly if not in body, then in spirit. The beautiful Tullia demonstrates, through her appearance as well as her philosophical stance, that sex makes one better, more articulate, spiritual and intelligent.

But the movement in erotic literature from the old hag to the young beauty is perhaps symptomatic of an even more profound transformation in erotic literary discourse. Michel Foucault, in $L$ 'usagedes plaisirs, the second of his three-volume Histoire de la sexualité, suggests a model which is useful in understanding this transformation. In the chapter entitled "L'acte, la dépense, la mort", he describes the anxiety with which different cultures have approached sexuality as resulting from its having been identified with its more "virile"attribute (ejaculation) and thus with the notions of violence, personal expenditure, and death. He goes on to describe three cultural responses to this sexual anxiety: the Chinese erotic art where, by entering into contact with and mastering the "life force" of the sexual partner one is in fact rejuvenated; the Christian pastoral which, through Confession, codifies sexual acts, moments and intentions, and legitimizes what is seen as a negative sexual impulse; and, among the Greeks, a diététique, techniques which allow one to philosophically stylize oneself through sex and "faire de sa vie une oeuvre qui se survivra au-delà de son existence passagère. ${ }^{13}$

Historically the, "rejuvenate, "legitimize, "and "stylize, "can be said to represent three cultural antidotes to a virile sexuality, three avenues of escape from the otherwise inevitable encounter with sexual anxiety--- the sex and death equation. If the erotic figure of the used-up old crone confirmed a negative view of sex the Dialogues pedagogy of sexual pleasure places these three imperatives in the service of a new rhetorical art. They

\footnotetext{
${ }^{13}$ Paris: Gallimard, 1984, p. 156.
} 
construct a new erotic rhetoric by inventing a discourse of "feminine" sexuality based precisely on these three strategies of escape: rejuvenate the body through the limitless proliferation of sexual encounters in a multi-orgasmic utopia; legitimize the practice through language (lies and storytelling); and stylize oneself through the studied pursuit and practice of pleasure. I would like first to consider the way in which the Dialogues demonstrate this last strategy of stylization or construction of one's existence.

Foucault analyzes the concept of "Diêtétique" in ancient Greek culture by examining the way in which diet and daily regimen is described and advocated in "prescriptive" manuals and texts. The diet is, according to Foucault, a fundamental category through which one thinks human behavior; it provides a set of guidelines with which to understand one's conduct; "un mode de problématisation du comportement, qui se fait en fonction d'une nature qu'il faut préserver et à laquelle il convient de se conformer. Le régime est tout un art de vivre" (115).

Foucault's definition of the "régime" covers four points: the object of the regime is the control and mediation of food, drink, exercise, sleep and sex; its goal is the health of the soul via care of the body; it is practical in that the regimen is a strategic art enabling one to deal "reasonably "with the circumstances of life; and it is taught, not as a set of rules which must be blindly obeyed, but persuasively, taking into consideration the individual's circumstances, and appealing to his intellect.

In their parody of the pedagogical dialogue form the Dialogues de Luisa Sigea evoke these ancient regimentary practices, specifically the sexual ones. Their purported therapeutic effects are exaggerated and a direct connection is drawn between sexual activity and "right thinking". Furthermore, the Dialogues' advocation of extra-marital sex forces the young woman to take an active role in determining and dissembling her sexual activities; this self-conscious and deliberate pursuit of erotic pleasure eventually leads to a stylization of the female subject and the development of her own "art de vivre."

Immediately after her wedding night, Ottavia has already noticed a difference in herself. She relates to Tullia her mother's profound, if somewhat hypocritical, remarks on the causes of a bride's new-found wisdom:

Ottavia. "Ce rôle d'épouse...est pour nous la source la plus certaine d'une saine raison;... En même temps que nos maris injectent la volupté dans nos corps, par le même canal, excellents ouvriers, ils y injectent la saine raison".

Tullia. Qui donc en douterait? Tu en es toi-même la meilleure 
preuve, toi qui, avant ces jours-ci, savais à peine t'exprimer et qui maintenant fais toutes choses et en parles si bien, si ingénieusement, si agreablement.

Notice that "saine raison" is acquired through sex and produces eloquence and volubility. (More on this later.) Encouraged, Ottavia waxes philosophic, inventing an image of sex as physical therapy for a dormant intellect:

Ottavia. Chez nous, on pourrait le dire, en un même endroit résident notre virginite et notre raison, les deux plus précieuses choses de la vie. La baguette virile, ouvrant notre sac, ouvre les voies a notre raison, blottie là depuis la naissance, et il se trouve qu'à force de poussées et de chocs, elle la fait bientôt monter de ce bas séjour vers des régions supérieures. (I,86)

Tullia once again agrees and adds jokingly that the "mentule" has the power to create "mental faculties".

The connection between defloration and intellectual enlightenment is a commonplace of classical erotic literature: losing one's virginity is, as suggested by the title of La Fontaine's conte, "Comment l'esprit vient aux filles. ${ }^{14}$ What would become a commonplace of 18 th-century erotic novels is the technique which Tullia next uses in order to reorient Ottavia's notions of honor and marital fidelity: she undermines Ottavia's belief in her mother's irreproachable behavior by recounting to her some of her mother's debauched adventures. ${ }^{15}$ Dazed by what she has just learned about a woman whom she believed "la plus pudique et la plus honnête des femmes, "but intellectually enabled by her recent sexual experience, Ottavia is now ready to receive a truly libertine education. Tullia delivers a complicated philosophical argument in favor of promiscuity: a woman is responsible for her own pleasure but also for her reputation; since even completely innocent women can get a bad reputation it does not make sense to refrain from pleasurable activities; rather one should allow oneself all pleasures that can be had discreetly and with no threat to one's honor.

Tullia. Ce que tu pourras faire commodément, sans avoir rien a

${ }^{14}$ Nouveaux contes de Monsieur de La Fontaine (1674) in Contes et Nouvelles en vers, edited by Georges Couton. Paris: Garniers Frères, 1961.

is This technique is used to seduce Cécile in Les liaisons dangereuses (1782) and it forms the thetorical basis of a philosophy of the degradation of the mother in Sade. 
craindre de ton mari, sois persuadée que cela t'est permis; ce que tu ne pourras faire sans courir un danger certain, n'hésite pas à croire que cela t'est défendu. Pour le moment, j'ai à t'inculquer les préceptes de la véritable et saine sagesse; grâce à cux, tu régleras dorénavant le cours de ta vie. Je leur suis redevable de tous mes bonheurs, de l'intacte conservation de ma bonne renommée, tandis que je m'amuse, que je jouis librement des avantages de la jeunesse; tu leur devras également ta félicité.

What Tullia then outlines is essentially a regimen of moral and behavioral duplicity designed to permit the pursuit of endless erotic adventures while keeping the appearance of honnêteté.

Tullia...Ce n'est pas en la chose elle-meme que consiste l'honneur ou le déshonneur, ... Veux-tu vivre agréablement et heureusement, Ottavia? pense que tout te soit à la fois permis et défendu. Que ce soit la ton souverain precepte, dans la condition d'existence que t'a adjugée la loi de mariage. (112-113)

What likens Tullia's discourse to the manuals of diététique studied by Foucault is the emphasis it places on rules and regimentation, moderation, and "healthy" wisdom. Of course the true "diète" were practices aimed at the (male) body--diet, exercise, sleep, sex--- with a view to the health of the soul. Tullia's instructions are indeed aimed at the body, but the goal of her lessons in the "art of existence" is not transcendental; she does not turn her life into a work of art in order for it to survive her death. Rather she teaches that it is only through careful planning, duplicity, and attention to appearances--practices which are essentially stylizing--that a woman can have any pleasure before her death. Tullia's regimen emphasizes those aspects of the "diète" which have a practical pedagogical function: she teaches that passive submission to a husband's desires is a sad waste of one's sexual capacities. A woman "owes it to herself" to take lovers: the pleasure she gets from them is of a different quality than that which her husband offers precisely because she actively seeks it, evaluates it, relates it to herself and to her body. Tullia's is a strategic art - the adulterous woman must know how to control situations and her own desires so as never to be discovered; for her this art is, as Foucault defines the regimen - "une sorte de manuel pour réagir aux situations diverses dans lesquelles on peut se trouver; un traité pour ajuster son comportement selon les circonstances" (121). Tullia proposes a set of behavioral guidelines which, if carefully followed, will, within a cultural and economic system which places a woman entirely at the disposal of her husband, grant her limited control over her sexual activities 
and permit her to live "agreeably" and "happily".

The use of the "Diététique" as a model for female sexual education in the Dialogues acts as a parody, to be sure, of ancient philosophical-pedagogical dialogues; as parody it contains a critique of societal values, in this case that of a bourgeois and hypocritical concept of honnêteté. But parody is also a creative form; in its juxtaposition of unrelated discourses parody produces literary hybrids. The Dialogues juxtapose a discussion of female pleasure with ancient philosophy producing a "feminine sexuality" cloaked in a virile pedagogical discourse of self-control. Just as the substitution of Tullia for Macette throws a positive light on the concept of female sexual education, the creation of a feminine sexual regimen makes it not only possible but necessary to depict women's pleasure and to offer it as the object of "serious" and detailed discussion.

I pointed out above that the Dialogues illustrate three avenues of escape from a sexuality of violence, expenditure and death; in so doing they create what I have called a classical erotic rhetoric. As we have seen, "Stylize",and/or the parody of stylizing, is an avenue by which "feminine sexuality" gets introduced into the arena of possible subjects of serious discussion. In the remaining two strategies of deviation, "rejuvenate" and "legitimize", this "feminine sexuality" will take form as it redefines the concept of ultimate pleasure and refunctions the Christian practice of penance.

Sexual activity is equated with "rejuvenation" in the Dialogues. The sexual encounter is portrayed, not as an "act" but as a series of tableaus or postures in an unlimited, multi-orgasmic, world; expenditure is not of one's life force but of an always renewable physical energy.

As in an erotic art, sexual pleasure suppresses the perception of time and the effects of its passing. Tullia tells Ottavia that an amorous session lasting forty-five minutes seems like two centuries when measured in raptures: "C'est par des siècles pareils, sans doute, que toutes les générations des êtres vivants perpétuent avec tant de plaisir leur éternité" $(I, 61)$. Sexual activity, when it results in reproduction, is life generating and also regenerating. At no point in Ottavia's education are the debilitating effects of pregnancy and childbirth addressed. And though Tullia revels in her depiction of the pain and violence associated with the loss of virginity, she insists that this pain is brief, a small price to pay for admission to a new life of indescribable pleasure. While doctors of the 16 th and 17 th centuries often prescribed sexual penetration as a remedy for a number of gynecological illnesses, Tullia rhetoricizes the curative properties of love-making: kisses are a baume vivifiant meant to revive a 
lover dying of pleasure; semen is a baume vital administered to a mourante in the throes of passion; Lampridio, after sex, feels "merveilleusement restauré... rempli de bonheur."

Tullia's remedy for physical exhaustion is always more sex, for which she prescribes various aids, restorative drinks, changing partners and positions. In the midst of an orgy she tells a flagging Ottavia to rekindle desire by changing positions: "Il faut assaisonner de la sorte la volupté, pour que de la volupté renaisse, sans fin, la volupté" (II, 36). Depletion of one's life force, the "expenditure" associated with a viril sexuality, does not exist in the feminine sexual regimen where loss of virginity, threat of pregnancy and physical exhaustion, when they are mentioned at all, are subordinated to a higher intention, that of multiple orgasm, or endless "volupté."

In other words, one climax following upon one sexual act of greater or lesser duration does not constitute the ultimate pleasure. The ultimate pleasure is to be found rather at some point within a series of sexual encounters: Tullia tells Ottavia that ten jousts are needed in order for her to reach "lecomble de la volupté". She orchestrates seven of these encounters for her student as she artfully deploys first Lampridio, then Rangoni, in carefully described positions that resemble the "fucking machines" of Sade.

Notice that, as in Sade, the meaning of the sexual episode is not found in the climax, the closure which defines it as an act, but in the series itself, in a taxonomic deployment of the many positions, places, circumstances in which one can have an orgasm. In Sade, the taxonomy itself is therefore sexually invested, that is, it acquires an erotic meaning in a mirroring of the procedure by which sex is taxonomized. In the same way education is eroticized in the Dialogues by using pedagogical language and educative techniques (taxonomies, etymologies) to prepare for and describe Ottavia's sexual initiation.

The Dialogues' multi-orgasmic utopia is dependent upon the depiction of a female sexual education. That is, while her male partners must alternate with one another, one always employed in a position while the other retires to regain his erection, Ottavia's capacity for multiple orgasm makes possible her uninterrupted apprenticeship into a range of sexual practices. The fact that sexual activity is rejuvenating, that it no longer represents a depletion of vital energy, is in keeping with the pedagogical spirit of the classical age, where education too is meant to be nontaxing, readily accessible, or, as the purported educative tand edifying) 
project of the Dialogues is defined in its preface,--a "sugar-coated remedy". ${ }^{16}$

\begin{abstract}
And such a man those "artists of confession" make; for what has the "art of confessing" done except to destroy the art and practice of confiding, until at last we have learned to confess a great deal, to confide not at all. (Luther, Confitendi ratio)
\end{abstract}

The third alternate rhetorical route employed in the discussion of sex in the Dialogues I have called "legitimizing". In Foucault's analysis (op.cit.) "to legitimize" is the goal of the Christian pastoral, the Medieval system of "cure" or "care" of the soul in which a spiritual guide elicits the confession of various deeds from the individual, evaluates their sinfulness and assigns punishment sufficient to expiate the offense and reconcile the individual with the church. As regards sexual activity, Foucault calls this spiritual guidance a "technology of the flesh"; its function is to obviate the negative or deleterious effects of sex -that is, sex as sin,-through a careful codification of inappropriate gestures and sexual moments (after childbirth, during menstruation, on certain holy days) followed up by exhaustive and detailed confessions of any divergence, on the part of the individual, from this code. Indeed, Foucault considers sexual discourse in the West to have developed around the concept of "confession" from the Middle Ages through the 17th century. But while the term "confession" groups together, in his analysis, a variety of techniques whose goal is to uncover or produce some truth about the individual, the actual practice of confession is but one well-defined part of the sacrament of Penance, a practice with its own

\footnotetext{
${ }^{16}$ The prefatory texts of the Dialogues, those supposedly written by Luisa Sigea as well as those written by anonymous editors and admirers, claim that the project of the text is to paint the vices and debauchery of Tullia and Ottavia, and to paint them in a charming and entertaining way, in order to dissuade other "honnete" women from following their example: "Un habile Médecin augmente la force des remèdes, en écartant d'eux la tépugnance et le dégoût, lorsq'il les fait prendre dans des sucreries; telle était la pensée de Luisa;...elle qui si ingénieusement, si plaisamment, avait su mêler l'utile à l'agréable." (p. XXXVI) The logic of this project is unabashedly twisted, an obvious parody of the literary and pedagogical propaganda of the period, and its insistence on "instruire et plaire".
} 
history and textual development. To better relate Foucault's analysis of confession to the development of a classical erotic rhetoric, it is necessary to examine certain moments in the history of Penance which Foucault neglected to consider, namely, the use of the penitential manuals, and their relationship to confession and pedagogy.

Penance, one of seven sacraments of the Catholic church, can be defined roughly as confession, punishment and absolution. Until the beginning of the sixth century penance was an act of public humiliation, punishment and redemption, so dramatic in its effects that the layman was expected to have recourse to it only once in a lifetime. With the increasing acceptance among the clergy of private confession and private penance, worshippers began to confess more regularly, and, in response to its growing popularity, the 1215 Lateran Council enjoined the faithful to confess their sins to a priest once a year.

But the status of penance and confession were severely debated in the church up until 1215. Much of the debate turned around the validity of the penitence manuals, the handbooks which priests used to learn the various kinds of sins and the punishment appropriate to each. Their instructions were so specific in nature that they were bound to be, occasionally if not frequently, in contradiction with other manuals and, though most claimed to be based on the writings of the Church Fathers, they were often accused of being inconsistent with one of these. I give an example from one of the most famous of these, the So-called Roman Penitential of ca. 830, in order to show the specificity of offenses included:

If any man who is betrothed defiles the sister of his betrothed, and clings to her as if she were his own, yet marries the former, that is, his betrothed, but she who has suffered defilement commits suicide-..-all who have consented to the deed shall be sentenced to ten years on bread and water. ${ }^{17}$

Offenses are organized under broad headings such as "Of Homicide", "Fornication", "Perjury" and the prescriptions of Penance range from the singing of psalms to abstention from "juicy foods" and from intercourse with one's wife.

While penitential manuals were originally written in Latin during the Middle Ages to instruct priests in the kinds and amounts of penance required for different sins, during the 16 th century, many were translated

\footnotetext{
${ }^{17}$ Translated in Medieval Handbooks of Penance, by John T. McNeill and Helena M. Gamer. New York: Octagon Books, 1979, p. 304.
} 
into the vernacular and addressed to the lay worshipper as confession came to be practiced more and more often. For the layman, the handbook had become necessary to help him/her learn the different sins (mortal and venial) and how each were to be confessed. This excerpt from the $D e$ poenitentia et tentationibus religiosorum (1189) illustrates how specific the confession itself was expected to be:

Confess therefore what thou hast done, as thou hast done it, and when thou hast done it, and in what measure thou hast done it, and where thou hast done it, and who thou art who hast done it, and who and what manner of person it is, with whom thou hast done it: or if it be impersonal, what it is. If thou wilt be safe confess all these circumstances with the number of the occasions, and the measure of the gratification, and the statement of thine age. ${ }^{18}$

The operative, and in fact menacing, line here is "if thou wilt be safe". The seed was planted for a confessional practice rooted in the "detail". Indeed, when the 1551 Couneil of Trent reiterated the Lateran injunetion to confess once a year, it included a special explanation of the importance of enumerating all the sins "specifically, and one by one".

Although Foucault admits some fluctuation in the role or importance of confession at various points from the Middle Ages through the 17th century, he maintains its overriding influence on the individual's relationship to sexual activity (the flesh). While this overview is undoubtedly correct it obscures the importance of one moment in the history of the Church and the sacrament of penance - the period of the Reform. That is, while Foucault claims that Catholic and Protestant views on confession have run a more or less parallel course, as Pierre Legendre points out, "confession was at the very heart of the reform movement". ${ }^{19}$ But, and more importantly, the debate on confession for 16th century religious thinkers turned around the question of confessional detail.

While Luther believed confession, though not strictly necessary for forgiveness and absolution, might be useful to the penitent, he warned against taxing one's memory with "a mass of details". He referred to the

"Anonymous Benedictine, quoted in Watkins, A History of Penance, p. 746.

19'amour du censeur: essai sur l'ordre dogmatigue. Paris: Seuil, 1974, p. 161. The chapter "Politique des confesseurs" gives a psychoanalytic reading of the relations of Penance to Scholasticism and Power emphasizing the importance of pedagogy to confession: that is, confession is a strictly coded riusal whose very content, what is confessed, is rigorously controlled; one learns to confess what one has been given to confess. 
differentiation between sins as "a riot of distinctions", that "hateful and wearisome catalogue". The problem with this detailed form of confession, to Luther's mind was that the penitent,

while seeking out forgotten sins or a way of confessing them, ...entirely loses the present pangs of conscience, and the whole profit and salutary effect of confession. When he is absolved, therefore, he rejoices not so much because he is absolved, as because he has freed himself once for all from the wretched worry of confession; for what he has been seeking has been not the absolution, but rather the end of the laborious nuisance of confessing. (Works, I, 91) ${ }^{20}$

Neither Calvin nor Luther believed confession to be a sacrament; Luther even advocated taking an occasional unconfessed communion, to prove one's faith in God's power to forgive over the power of individual acts of confession. Calvin would dispense with auricular confession altogether. He believed that the only people who approached confession with joyful heart were the priests "whopleasantly entertain themselves with mutual narrations of their exploits, as with humorous anecdotes." To support his argument against confessional practice he reminds his readers of the Patriarch Nectarius' decision to abolish confession in Constantinople, in 391. The determining factor here, was, as might be expected, of a sexual nature.

I only remark, if that holy man was not guilty of indiscretion, who, on account of one numour of fornication, banished confession from his church,... we are thus reminded of what ought to be done in the present day, when rapes, adulteries, incests, and seductions exceed all enumeration. (Institutes, Book III, chap.IV, XIX) ${ }^{21}$

For Calvin too, the problem with confession was to be found in the detailed enumeration of sins, the recounting of amorous adventures and the narrating of sinful acts.

According to H.-J. Martin, the Catholic church responded to the reformers accusations by attempting to control the conditions under which the sacrament of penance was administered. Dominicans, Franciscans and

\footnotetext{
${ }^{20}$ Luther, Martin. Works. 6 vols. Philadelphia edition. Philadelphia: Muhlenberg Press, 1930-43.

${ }^{21}$ Calvin, Jean. Institutio christianae religionis. Ed. John T. McNeill. Transl. Ford Lewis Battles. Philadelphia: Westminster Press, 1960.
} 
especially Jesuits organized a pedagogy of moral theology, creating chairs in their colleges dedicated to that specialty. Martin explains the concomitant explosion in the early 17 th century in the publication of confessional manuals, which, by the way, continued and augmented the amount of detail required of the penitent:

\begin{abstract}
la nécessité de développer l'instruction du clergé et de lui donner des directives en matière de confession incita les docteurs ainsi spécialisés à composer des traités de morale pratique et même utilitaire, et à s'efforcer de résoudre avec plus de précision que dans les manuels jusque-là en usage, les cas de conscience qui pouvaient tetre soumis aux directeurs. $(I, 123)^{22}$
\end{abstract}

The importance attributed to the sacrament of penance influenced the visual arts as well contributing to the development of a specialized "penitential" iconography distributed in the form of illustrated books and popular engravings. Figuring prominently were representations of a repentant Saint Peter and a weeping Mary Magdalen.

The debate over confessional practices continued during the 17th century as part of the Jansenist-Jesuit controversy over questions of Grace and Penance. The Jansenists, like the protestants, were critical of the use made of the sacrament by unrigorous or, what they considered to be, uninformed spiritual directors. Their views were stated in numerous polemical texts and refutations supporting their side of a quarrel which began with the publication of the Augustinus and Antoine Arnauld's treatise $D e$ la frequente communion. ${ }^{23}$ In the latter treatise Arnauld advocated the reestablishment of the practice of public penance which he believed to have fallen out of favor as a result of the lenient and therefore more popular practice of private confession. Amauld thought that confession in fact had taken the place of penance, that directors were more concerned with the meticulous recounting of the sinful act than with obtaining the correct penance in expiation of it. Some people, he claimed, expected to skip penance altogether: "ily en a beaucoup qui se persuadent, que pourveu qu'ils ayent fait le dénombrement de leurs pechez, du même

\footnotetext{
${ }^{2}$ Livre, pouvoirs et sociêté d Paris au XVI siècle. 1598-1701. 2 vols. Geneva: Droz, 1969.

${ }^{23}$ De la fréquente Communion, ou les sentimens des Peres, des Papes, et des Conciles, touchant l'usage des Sacremens de Penitence \& d'Eucharistie, sont fidellement exposez: Pour servird'adresse aux personnes qui pensent serieusement d se convertir d Dieu; \& aux Pasteurs \& Confesseurs zelez pour le bien des ames. Lyon: 1683. First published Paris: Vitre, 1643.
} 
ton que l'on conteroit une histoire, \& qu'ils ayent promis des levres de s'en repentir. . .ils ont droit de recevoir l'absolution..."(634). Arnauld was scandalized because the sacrament had been reduced to a narrative act devoid of feelings of remorse: people confessed "as if they were telling a story". And in another passage Arnauld recorded the oft-heard complaint of an unnamed theologian friend: "Nous sommes en un temps où on a soin de raconter ses pechez, \& non pas de les détester" (581).

Arnauld's critique addressed only the most obvious of the dangers associated with a very narrative concept of penance; he decried what he believed to be the replacement of the sacrament of Penance by confession. Indeed, the Jesuits had innovated on the narrative practices of confession, pushing it well beyond the penitential function originally assigned it. The very popular confessional guide, the Somme des pechez qui se commettent en tous estats by the Jesuit Bauny, ${ }^{24}$ demonstrates, in its general description of confessional procedure, the extent to which the confession was inclined in fact to encourage narrative fabrications - through the promptings of the confessor, or the approximations of the penitent. At a normal confession the penitent is supposed to accuse himself if he can; "sinon il le faudra soulager en l'interrogeant des pechez que l'on pense probablement qu'il a commis", the most common being superstitions, swearing, quarrels, desiring dishonest and shameful things, not going to Mass, getting drunk, etc. He needs to accuse himself of all of these things, and count their number; but if he can't remember, "suffitde dire le temps auquel l'on pense avoir esté le subjet à semblables imperfections, avec l'inclination à les commettre à peu près tant de fois en un jour, plus ou moins."

The confession of "imagined" sins is discussed and developed further in the chapter "Des choses dont il faut interroger le Penitent en fait de Luxure" where dishonest thoughts and the pleasures they provide are theorized. Here is sorted out the difference between those thoughts which are not evil in themselves, since predicators and confessors are obliged to have them and listen to them recounted; and those which are pernicious because of their consequences. If one has more than passing lubricious

\footnotetext{
${ }^{24}$ Somme des Pechez qui se commettent en tous estats de leurs conditions et qualitez En quelles occurrencesils sont Mortels ou Veniels \& en quelle façon le Confesseur en doit interroger son Penitent par le R.P.E. Bauny de la Compagnie de Jesus. Paris, 1633, p 84. First published in 1630, this extremely popular and controversial manual was, according to H-J Martin, reedited or reprinted in $1633,34,35,36,39,41,43$, and 46 . It experienced a 4-year condemnation by Rome, the Sorbonne, and the French Assemblé du clerge for reasons of laxity, from 1640-44.
} 
thoughts, and represents to oneself the sex act and derives pleasure from that representation, then the thoughts are a mortal sin and "le confesseur ... s'en fera dire autant qu'il pourra le nombre, comme aussi des delectations, qui avec deliberation se treuvent par fois en la partie inferieure" (110). As in the 1189 De poenitentia manual mentioned above, where the "measure of gratification" is to be calculated, the penitent reader of Bauny's manual is asked not only to tell the number of such thoughts, but the kind of pleasure which they provide.

But the interrogation of sinful thoughts delved still deeper into the fictions produced by the penitent. Bauny related the two sides to an evidently controversial point of casuistry having to do with the admission of the identity or status or identity of the imaginary partner. On the one hand it was argued that the penitent must tell the condition of his imagined partner, whether she is a sister, a virgin, another's wife, because the pleasures to be had to differ depending on the objects ("Car tous ces plaisirs sont differens d'espece entre-eux, ne plus ne moins que les objets qui les terminent", [121]). Others said that if the penitent did not intend to act on those things he had imagined, then he had no other pleasure than what he imagined to be in the carnal act; the pleasures were all then of the same type. Notice here that the operative word is pleasure and not sin; in this part of the confession, sin is determined by the quality of pleasure experienced as recounted by the penitent who, furthermore, is asked to evaluate this pleasure. The confessional manual began to resemble a treatise on sexual pleasure or a technical guide to erotic representation.

What was at stake, then, in the debate over penance was originally, the status of the manual, the basis of its pedagogical authority; during the Reform was added a new concern for the necessity of descriptive detail which the manual was designed to encourage and facilitate. These manuals taught people the "art of confessing"--that is, the way to represent sin, to exteriorize it and to sublimate guilt, "the pangs of conscience", into the narrative act. Reformers perceived what they considered to be the dangers of the confessional; it was a school for storytelling and a veritable bonanza of titillating anecdote.

The Dialogues de Luisa Sigea comment on this debate, they parody it, and in so doing represent perhaps the earliest exploitation of the 
erotic potential of confession in literature. ${ }^{25}$ In the Dialogues Tullia and Ottavia are keenly aware of the erotics of confessional practice. They have learned to manipulate it, employing confessional formula as a mechanism to generate the narration of sexual pleasure and then to transform it into the pleasure of narrative.

The episodes involvingthe stoic philosopher Teodoro are the most obvious reference to Christian confession, and represent what I called earlier the telescoping of early modern concerns into ancient themes. The Christian spiritual director, or guide of souls, was in many ways related to the Graeco-Roman sophist or stoic philosophers who conducted their own systems of public and private penance. The ingenue Ottavia tells how, in anticipation of the loss of virginity which her wedding night would bring, she was brought by her mother to see one of these philosophers, Teodoro, to confess and to expiate at his hands her future sexual impurity. Tullia encourages her to relate the episode "point by point". So, in great detail, Ottavia describes her confession and tells how Teodoro watched and assisted as both she and her mother took off their clothes and were flagellated. A still naive Ottavia doesn't yet know the sensual dividends of such a ritual. Her mother, on the other hand, does: Tullia explains that her mother endured it stoically, and then, stimulated by the thrashing, she took her stinging buttocks out of the confessional and directly into the bed of her lover. Later in the Dialogues Ottavia entertains Tullia with the story of how Teodoro is joined by another philosopher, and, as the spiritual guides have sex with both Ottavia and her mother, the pleasure of the confessional finds an immediate and unsublimated expression.

Throughout their discussions, Tullia and Ottavia attempt to justify and to define a rhetoric of erotic representation. In the chapter aptly entitled "Historiettes" they discuss the use of narration to reenact, prolong, and intensify sexual pleasure. Their dialogue is punctuated with the confessional imperatives "Parle," "Continue," and with questions designed to bring as many reality effects as possible to the recounting of amorous adventures. The resulting narrations emphasize a new technique of erotic representation which would have a profound influence on the development of the 18th-century novel: the magnification and celebration of the narrative detail.

2s From the Middle Ages to the Renaissance there was a literary tradition of anti-clericalism which often portrayed the monk or spiritual guide as a horny satyr who makes use of his confidants role to prey on and corrupt an innocent young woman. What is different about the classical portrayal of the director of conscience is the emphasis placed on the confession itself, and on the narration of sinful acts. 
For example, Ottavia relates her experiences with a young boy, a little Cupidon whom she calls "l'Amour en personne"; Tullia interrupts her only to ask for precisions on the size of his penis and to link, metaphorically, the erotic power of the "little penis" with that of the rhetorical detail: "Parmon bon géniel cette ingénieuse narration me donne une démangeaison inaccoutumée. Tu es une étonnante conteuse de riens: Aux petites choses grande peine et gloirenon menue" (II, 163). Toward the end of the Dialogues the incitation to narrate becomes what reformers had predicted: it is an apology for erotic representation. Ottavia, now fully fashioned in erotic rhetorical techniques, attempts to persuade a shy friend to talk about her wedding night: she argues that some people find "suprême voluptén in the hope or the memory of pleasure; that some get more pleasure out of recounting their "jouissances" than in experiencing them; that the remembrance of pleasures turns a fleeting experience into a durable one. She makes a connection between narrating pleasure (l'ombre de la volupté) and living well. And finally, she dissolves the distinction between the experience of pleasure and its shadow-form, the artful narration. Through cultivated lubricity dreams can come true: "Veux-tu vivre bien et heureusement? détache des fruits, cueille des roses dans les jardins de Vénus. A la savante luxure tout réussit à souhait. Même dans l'ombre de la volupté tu rencontreras la volupté véritable" (II, 92).

The Dialogues create a new erotic discourse based on a 17th-century construction of feminine sexual behavior: multiple orgasm, lesbian relations, a lack of personal expenditure. While it is true that the Dialogues were written by a man, in latin, for men, while it is true that lesbian evocations are a lieu commun of male erotic phantasy, it is all the same difficult to read certain parts of the Dialogues de Luisa Sigea without feeling that something very new was developing out of erotic representation in the middle of the 17th century. This midcentury liberation of Western erotic narrative from a morbid, virile model was indeed short-lived: but before Tullia's lessons in the analysis of pleasure are replaced, in the 18th century, by Sadian lessons of cruelty and expenditure, and before she allows into her philosophical boudoir a male accomplice who outshines or dominates her, the 17th-century figure of the female sexual pedagogue will shape erotic discourse into a titillating, regenerating, rhetorical art. It is talk, more precisely it is girl-talk, that deflowers Ottavia; via the pleasure of communication even heterosexual intercourse is transformed into a homoerotic fusion of souls.

Tullia. J'ai toujours pensé, mon amour, non pas que tu étais une autre 
moi-même, mais que tu ne faisais qu'une avec moi. J'ai expose devant tes yeux toutes mes passions, et je n'en ai pas eu honte. Je t'ai fait pénétrer dans les fibres intimes de ma poitrine, et je ne m'en repens point; parle. (II, 150)

"Parle", the incitation that Foucault sees as having dominated, since the Middle Ages, the West's sexual practice, finds its confessional function confirmed in the Dialogues, but in a twisted form. Here the aim is not to regulate and codify pleasure, but to make it proliferate. That is, go on, talk, but so that the pleasure never ends:

Bonne Vénus! lorsque je pense, ma Tullia, à de telles voluptes, mes moelles intimes s'enflamment d'une aveugle ardeur. N'en est-il pas de méme de toi?

Tullia. Je délire, sotte; continue. Tu me plais merveilleusement avec ce récit. (I, 199)

\section{University of Texas A \& M}

\section{RUTH LARSON}

\section{Bibliography}

Aretino, Pietro. Opere di Pietro Aretino e di Anton Francesco Doni. Tomo II. Milano, Napoli: Riccardo Ricciardi, 1976.

--.. Aretino's Dialogues. Trans. Raymond Rosenthal. New York: Stein and Day, 1971.

Amauld, Antoine. De la Fréquente Communion...touchant l'usage des Sacrements de Penitence et d'Eucharistie. 9th edition. Lyon: 1683.

Bailbe, Jacques. "Le thème de la vieille femme dans la poésie satirique du seizième et du début du dix-septième siècles." Bibliothzqque d'Humanisme et Renaissance xxvi(1964): pp. 98-119.

Baudelaire, Charles. Oeuvres Completes. Ed. Claude Pichois. 2 vols. Paris: Gallimard, 1976.

Bauny, E. Somme des Pechez qui se commettent en tous estats de leurs conditions et qualitez. En quelles occurrences ils sont Mortels ou Veniels: \& en quelle faşon le Confesseur en doit interrogerson Penitent. Paris: 1633.

Calvin. Institutio christianae religionis. Ed. John T. McNeill. Trans. Ford Lewis Battles. Philadelphia: Westminster Press, 1960.

Chorier, Nicolas. Aloisiae Sigeae Toletanae Satyra sotadica, de Arcana Amoris, 
et Veneris. Aloisia Hispanice scripsit. Latinitate donavit Joannes Meursius. 1659-60.

.--. Des secrets de l'Amour et de Venus: satire sotadique de Luisa Sigea de Tolede. Revised translation of Alcide Bonneau. Ed. Andrew Berry. 2 vols. Paris: L'Or du Temps, 1969.

The Creeds of Christendom. Ed. Philip Schaff. 3 vols. Grand Rapids, MI: Baker Book House, 1966.

Cryle, P.M. "'Erotic literature': A first essay in improper thematics." French Forum 13:1 (1988): pp. 83-96.

DeLey, Herbert. "'Dans les règles du plaisir...' Transformation of sexual knowledge in seventeenth-century France". Onze nouvelles études sur l'image de la femme. Paris: Editions Jean-Michel Place, 1984.

Eroticism in French Literature. French Literature Series Vol. X. University of South Carolina, 1983.

Feminism and Foucault: Reflections on Resistance. Eds. Irene Diamond and Lee Quinby. Boston: Northeastem University Press, 1988.

Fleuret, Fernand and Louis Perceau. Les Satires francaises $d u$ XVII siecle. Paris: Gamier Frères, 1923.

-.-. Le Cabinet Satyrique. 2 vols. Paris: Libraire du bon vieux temps, 1924. Orig. ed. 1618.

Foucault, Michel. Histoire de la sexualité 3 vols. Paris: Gallimard, 1976-1984.

..-. "On the Genealogy of Ethics: an overview of work in progress." Interview. Michel Foucault: Beyond Structuralism and Hermeneutics. Eds. Dreyfus and Rabinow. Chicago: University of Chicago Press, 1983.

.... Power/Knowledge: Selected Interviews \& Other Writingsr 1972-1977. Ed. Colin Gordon. New York: Pantheon Books, 1980.

Fumaroli, Marc. L'Age de l'éloquence: rhétorique et "res literaria" de la Renaissance au seuil de l'époque classique. Geneva: Droz, 1980.

Grenade, Louis de. Le Grand Guide des Pécheurs. Trans. Paul du Mont. Lyon, 1609.

Kearney, Patrick J. A History of Erotic Literature. London: Macmillan, 1982.

Laclos, Pierre Choderlos de. Les Liaisons dangereuses. Ed. René Pomeau. Paris: Flammarion, 1981. 
La Fontaine, Jean de. Contes et nouvelles. Ed. Georges Couton. Paris: Gamier Frères, 1961.

Legendre, Pierre. L'Amour du censeur: essai sur l'ordredogmatique. Paris: Seuil, 1974.

L'Espine, Sieur de. La Macette du Sieur de L'Espine. Intro. E. Courbet. Paris: Alphonse Lemerre, Libraire, 1875.

Lorris, Guillaume de and Jean de Meun. Le Roman de la Rose. Ed. Daniel Poirion. Paris: Gamier-Flammarion, 1974.

Luther, Martin. Works. 6 vols. The Philadelphia Edition, Munlenberg Press, 1930-43.

Lyons, J Coriden. "Notes on Mathurin Régnier's Macette." Studies in Philology XXVIII (1931): pp. 301-303.

Magendie, Maurice. La Politesse Mondaine et les théoriesde l'honnêteté en France au XVII siecle de 1600 d 1660. 2 vols. Paris: Libraire Félix Alcan, 1928.

Martin, Henri-Jean. Livre, pouvoirs et sociêté d Paris au XVII siècle 1598-1701. 2 vols. Geneva: Droz, 1969.

Maurel, Madeleine. "Esquisse d'un anteros baroque." XVI siecle 84-85 (1969): pp 3-20.

McNeill, John T. "Historical types of method in the cure of souls." The Crozer Ouarterly.

McNeill, John T. and Helena M. Gamer. Medieval Handbooks of Penance. New York: Octagon Books, 1979.

Millot, Michel. L'Ecole des filles ou la philosophie des dames. Ed. Pascal Pia. Paris: L'Or du Temps, 1969.

Ovid (Publius Ovidius Naso). The Erotic Poems. Trans. Peter Green. New York: Penguin Books, 1982.

.... The Art of Love: Ovid's Ars Amatoria. Trans. B. D. Moore. London: Blackie \& Son Lid., 1935.

La Parodie: théorie et lectures. Etudes littéraires. Ed. Jean-Jacques Hamm. 19 (1986).

Régnier, Mathurin. Oeuvres completes. Ed. Jean Plattard. Paris: Editions Fernand Roches, 1930. 
.... Mathurin Regnier:Les satires. Ed. Robert Aulotte. Paris: Editions CDU et SEDES réunis, 1983.

Mathurin Régnier et les Satyriques. Le Cabinet Secret du Parmasse. Ed. Louis Perceau. Paris: Cabinet du Livre, 1930.

Rojas, Fernando de. La Celestina y Lazarillos. Ed. Martin de Riquer. Barcelona: Vergara Editorial, 1959.

-.-. Celestina. Trans. Mack Hendricks Singleton. Madison: University of Wisconsin Press, 1958.

Rose, Margaret. Parody/Metafiction. An Analysis of Parody as a Critical Mirror to the Writing and Reception of Fiction. London: Croon Helm, 1979.

Rosettini, Olga Tretnik. Les Influences anciennes \& italiennes sur la satire en France au XVI siecle. Florence: Institut Français de Florence, 1958.

Sade, Donatien-Alphonse-François de. Oeuvres complères du Marquis de Sade. Eds. Annie LeBrun and Jean-Jacques Pauvert. 15 vols. Paris: Pauvert. 1986.

Saisset, Léon et Frédéric. "Un type de l'ancienne comédie: l'entremetteuse." Mercure de France 15. viii (1922): pp. 116-129.

Searle, G.W. The Counter Reformation. London: University of London Press Ltd., 1974.

Tiefenbrun, Susan W. "Mathurin Regnier's Macette: A Semiotic Study in Satire." Semiotica 13:2 (1975): pp. 131-153.

Vianey, Joseph. "La Robe grise de Macette." Revue des Langues Romanes 45-46 (1902-03): pp. 30-32.

Watkins, O. D. A History of Penance. 2 vols. London: Longmans, 1920. 